\title{
Globalization and economic growth in highly developed countries
}

\author{
Stanisław Swadźba ${ }^{1, *}$ \\ ${ }^{1}$ University of Economics, Department of Economics, 40-287 Katowice, 1 Maja 50, Poland
}

\begin{abstract}
The main goal of this paper is to show the level of globalization, its changes and the impact of globalization on economic growth and socio-economic development in these countries. The following research methods were used: historical, literature, descriptive analysis and simple statistical methods. Statistical data used in this paper come from KOF Index of globalization, World Bank Database and Human Development Reports. The time range of research is 1990-2018. The research covered 16 countries of Western Europe, USA, Canada, Japan, Australia and New Zealand. The main findings of the study are as follows: Highly developed countries are the most globalized. The level of globalization in individual countries varies, but the differences are not large. The medium-size European countries are the most globalized, while non-European countries are the least globalized. Starting from the 1990s, the level of globalization has increased significantly. The highest increase was in the less globalized countries, the lowest in the most globalized ones. As a result, the differences between them have significantly decreased. Thus we can see the convergence in the sphere of globalization. The positive impact of globalization on economic growth and socio-economic development was not observed in this group of countries.
\end{abstract}

\section{Introduction}

The process of globalization encompasses an increasing number of countries. We all live in the globalizing world. In principle, there is no country that would not be affected by it. However, the level of globalization of individual countries is diverse. We can say that some of them are more globalized then others. There is no doubt that highly developed countries are the most globalized ones. Are there any differences between them? What changes are taking place in this group of countries? These issues are discussed in this study.

The main goal of this paper is to show the level of globalization, its changes and the economic growth that have taken place in highly developed countries. The aim is also to present the impact of globalization on economic growth and socio-economic development in these countries.

The impact of globalization on economic growth is one of the main aspects of the globalization studies. Researchers are increasingly interested in the process. Globalization

\footnotetext{
*stanislaw.swadzba@ue.katowice.pl
} 
is expected to promote economic growth for many reasons. First, international knowledge spillovers will certainly help to increase economic growth. Second, entrepreneurs have access to larger potential markets in open than closed economies. Third, entrepreneurs may well exploit comparative advantages and receive gains from specialization during globalization. Production will become more efficient and increase country's economic growth [1].

Crafts shows historical evidence on the relationship between globalization and economic growth [2]. The results of many empirical studies suggest that globalization has extended positive effect on economic growth. Globalization indeed promotes growth [3]. Several studies have shown that more globalized countries are also more sustainable [4]. The evidence shows that globalization has spurred economic growth, promoted gender equality and improved human rights. However, despite the increase, it contributed to income inequality $[5,6]$. Some studies try to show whether the globalization brings about the convergence in per capita income [7]. According to Gygli et. al, economic growth increases when de jure economic and political globalization as well as de facto social globalization are more pronounced [8]. Others suggest that rather developing countries instead of industrialised ones enjoy economic growth during globalization. For example, Bergh and Karlsson presented evidence for OECD countries [9], Samini and Jenatabadi for countries of the Organization of Islamic Cooperation (OIC) [10]. Hayaloglu showed that the impact of globalization on economic growth varies depending on the level of development of individual countries [11]. Is it really so? The attempt to verify some of these theses will be undertaken in this paper.

The research covered 21 highly developed countries, namely (in alphabetical order): Australia, Austria, Belgium, Canada, Denmark, Finland, France, Germany, Ireland, Italy, Japan, Luxembourg, Netherlands, New Zealand, Norway, Portugal, Spain, Sweden, Switzerland, United Kingdom (UK) and USA. These are the countries classified by the World Bank as the 'high-income economies'. The study did not cover all countries which belong to this group (there are as many as 80 economies). It did not include countries that have achieved high levels of GDP per capita in recent decades, e. g. oil producing countries or newly industrialised countries. GDP per capita was not the only selection criterion. The criterion of socio-economic development as well as the historical criterion were also taken into account. Only countries that were the first to enter the path of industrialisation and accelerated socio-economic development were selected. Hence, there are only 16 countries of Western Europe (small states such as Andorra, Iceland, Liechtenstein, Monaco and San Marino were omitted) and 5 non-European countries (USA, Canada, Japan, Australia and New Zealand).

The basis for considering the changes in the level of globalization is the KOF Index of Globalization [13] developed in 2002. It was introduced by A. Dreher [3] and updated in Dreher et al. [14]. The second revision of this index dates from 2018. It distinguishes between de facto and de jure measures along the different dimensions of globalization. It also discriminates between trade and financial globalization within the economic dimension of globalization and uses time-varying weighting of the variables. The new index is based on 43 instead of 23 variables in the previous version [8]. It is developed and published annually. In addition, the above index has been developed for earlier years. The other globalization indices do not have these features, for example, the first globalization index developed by A.T. Kearney and 'The Foreign Policy' [15, 16], CSGR Globalization Index [17], Maastricht Globalisation Index [18], New Globalisation Index [19] and many others [20]. KOF globalization index, despite some disadvantages, is the highest rated [21].

To describe the current level of globalization, the 2018 KOF Index of Globalization (rankings for the year 2016) was adopted, and the previous indices were used to highlight the changes [13]. The KOF index has three dimensions, namely: economic globalization, 
social globalization and political globalization. As a result, in addition to the global index of globalization, 3 sub-indices were created. Each of them is calculated on the basis of several indicators. In addition, each of them is assigned a specific weight. These indices will also be used in this paper.

Statistical data on economic growth and GDP per capita come from the World Bank [12]. Information about Human Development Index (HDI) for those countries originates from Human Development Reports [22]. The time range of the research is 1990-2018.

\section{The level of globalization}

The latest KOF globalization index (2018), as well as subindices, for highly developed countries and their place in the world ranking, is given in Table 1.

Table 1. 2018 KOF Globalization Index in highly developed countries.

\begin{tabular}{|c|c|c|c|}
\hline Globalization Index & $\begin{array}{c}\text { Economic } \\
\text { Globalization }\end{array}$ & Social Globalization & Political Globalization \\
\hline 1.Switzerland 91.17 & 2.Netherlands 89.01 & 1.Luxembourg 92.11 & 1.Italy 98.25 \\
\hline 2.Netherlands 90.97 & 3.Belgium 88.56 & 2.Norway 91.12 & 2.France 98.16 \\
\hline 3.Belgium 90.50 & 4.Luxembourg 88.34 & 4.Switzerland 90.64 & 3. Germany 97.56 \\
\hline 4.Sweden 89.88 & 6.Ireland 87.86 & 5.Canada 90.12 & 4.Netherlands 97.46 \\
\hline 5.UK 89.35 & 8.Switzerland 86.70 & 6.UK 90.11 & 5.Spain 97.45 \\
\hline 6.Denmark 89.14 & 11.Denmark 83.77 & 7.Denmark 89.87 & 6.UK 97.38 \\
\hline 7.Austria 88.95 & 14.Sweden 82.52 & 8.Sweden 89.82 & 7.Sweden 97.31 \\
\hline 8.Germany 88.17 & 17.Austria 82.03 & 9.Ireland 89.26 & 8.Switzerland 96.17 \\
\hline 9.France 87.20 & 18.Finland 81.70 & 10.Austria 88.74 & 9.Belgium 96.12 \\
\hline 10.Finland 86.99 & 22.UK 80.56 & 13.Germany 87.57 & 10.Austria 96.08 \\
\hline 11.Norway 86.40 & 24.Germany 79.39 & 14.Australia 87.33 & 11.Denmark 93.77 \\
\hline 12.Spain 85.30 & 25.Portugal 79.19 & 15.Belgium 86.69 & 12.USA 93.72 \\
\hline 15.Ireland 84.64 & 28.France 77.18 & 18.Netherlands 86.44 & 13.Finland 93.55 \\
\hline 16.Canada 84.38 & 30.Norway 77.13 & 19.NewZealand 86.32 & 16.Canada 92.80 \\
\hline 17.Luxembourg 83.73 & 36.Spain 75.32 & 20.France 86.25 & 20.Portugal 91.86 \\
\hline 19.Portugal 83.52 & 48.Canada 70.21 & 22.Finland 85.62 & 26.Norway 90.93 \\
\hline 22.Italy 82.59 & 49.NewZealand 70.21 & 23.USA 85.45 & 29.Australia 89.88 \\
\hline 23.USA 82.10 & 53.Italy 68.75 & 31.Spain 83.14 & 31.Japan 89.22 \\
\hline 24.Australia 81.58 & 62.Australia 67.54 & 45.Japan 80.82 & 65.NewZealand 77.66 \\
\hline 36.Japan 78.37 & 65.USA 67.12 & 46.Italy 80.78 & 67.Ireland 76.79 \\
\hline 39.NewZealand 77.91 & 74.Japan 65.08 & 50.Portugal 79.51 & 86.Luxembourg 71.17 \\
\hline
\end{tabular}

Source: [13].

The level of globalization of highly developed countries is very high. The first 12 places of the world ranking are occupied by them. 16 countries are at the top twenty. Switzerland is the most globalized country according to KOF (2018). It is followed by the Netherlands and Belgium, which reached more than 90 points (0-100). Next 16 countries reached from 80 to 90 points. The first 3 (Sweden, the United Kingdom and Denmark) almost 90 and next 6 countries - over 85 points. The last 2 countries (Japan and New Zealand) did not get 80 points. The lowest position in this group of countries was taken by 4 non-European countries. Only Canada is ranked higher ( $16^{\text {th }}$ position). The difference between the most and the least globalized country is not very big - about 13 points.

The Netherlands is ranked first in the economic globalization. Belgium was second, Luxembourg - third (Benelux countries). Together with next 7 countries they reached more than 80 points each. The other countries gained fewer points: 7 between 70 and 80, 4 less 
than 70. Non-European countries and Italy occupy last 6 positions. The difference between the most and the least globalized country in the economic globalization ranking is similar to the overall ranking. However, it is worth noting that only 5 countries are at the top ten and 9 at the top twenty. The last 4 countries are in the second half of the top '100.' Japan took $74^{\text {th }}$ place. Almost all countries gained much a worse position than in the overall ranking.

In the ranking of social globalization, Luxembourg took first place and together with Norway, Switzerland, Canada and the United Kingdom gained more than 90 points. Only Portugal gained less than 80 points and was placed on $50^{\text {th }}$ position in the world ranking. There are 9 countries at the top ten and 15 countries at the top twenty. The analysed group of countries took better position than in previous ranking, especially non-European countries (Canada is $5^{\text {th }}$ ). The difference between the most and the least globalized country is almost the same as in the previous rankings.

More diverse - compared to the earlier subindices - is the ranking of political globalization. Italy is the most globalized country (98.35), but next 6 countries gained almost the same number of points. 16 countries obtained over 90 points. As many as 15 countries are at the top twenty (10 out of the top ten!). Many countries occupy higher places in this ranking. At the end there are New Zealand, Ireland and Luxembourg. The last in this group, Luxembourg was only on 86th position with about 70 points, 27 points less than Italy (the biggest difference).

It is also worth mentioning de facto and de jure indices. For the analysed group of countries, de jure globalization index was 19 times higher than the de facto globalization index. The biggest difference was in Luxembourg (19 points), the USA, Japan (12 points), Portugal and Spain (10 points). Switzerland and Ireland were exceptions. In the first of them the difference was rather small, while in Ireland it was as many as 7.5 points. The situation was similar in the case of economic globalization, where de jure index was higher in 18 countries. The differences were even greater and amounted to 30 points in the USA and Japan and about 20 points in Australia and Canada. The diversity also occurs in the case of social and political globalization.

\section{The changes in the level of globalization}

The KOF provides the information that allows us to identify the changes that have taken place in the level of globalization in highly developed countries since the 1990s. It is shown in Table 2.

Table 2. KOF Globalization Index in highly developed countries (1990-2018).

\begin{tabular}{|c|c|c|c|c|c|c|}
\hline Country & 1990 & 1995 & 2000 & 2005 & 2010 & 2018 \\
\hline Switzerland & 79.00 & 83.40 & 88.71 & 88.64 & 89.23 & 91.17 \\
\hline Netherlands & 80.25 & 84.06 & 87.62 & 87.99 & 88.96 & 90.97 \\
\hline Belgium & 81.11 & 85.73 & 87.88 & 88.54 & 90.02 & 90.50 \\
\hline Sweden & 78.24 & 84.16 & 88.23 & 89.03 & 90.02 & 89.88 \\
\hline UK & 79.49 & 83.46 & 87.11 & 88.23 & 88.32 & 89.35 \\
\hline Denmark & 79.38 & 83.64 & 87.32 & 88.35 & 88.17 & 89.14 \\
\hline Austria & 75.80 & 82.53 & 87.23 & 88.27 & 88.04 & 88.95 \\
\hline Germany & 73.11 & 79.14 & 85.29 & 86.91 & 86.90 & 88.17 \\
\hline France & 75.66 & 79.66 & 84.20 & 84.83 & 86.30 & 87.20 \\
\hline Finland & 72.41 & 80.16 & 85.14 & 85.05 & 85.69 & 86.99 \\
\hline Norway & 76.75 & 81.45 & 84.75 & 84.30 & 85.60 & 86.40 \\
\hline Spain & 64.38 & 74.83 & 80.94 & 81.98 & 82.95 & 85.30 \\
\hline Ireland & 73.74 & 79.42 & 82.91 & 83.63 & 84.68 & 84.64 \\
\hline
\end{tabular}




\begin{tabular}{|c|c|c|c|c|c|c|}
\hline Canada & 71.56 & 78.29 & 83.18 & 82.32 & 83.04 & 84.38 \\
\hline Luxembourg & 74.58 & 78.58 & 81.82 & 83.40 & 87.37 & 83.73 \\
\hline Portugal & 61.28 & 73.55 & 79.49 & 80.42 & 81.93 & 83.52 \\
\hline Italy & 69.44 & 73.84 & 80.90 & 79.78 & 80.87 & 82.59 \\
\hline USA & 70.59 & 75.01 & 78.19 & 79.48 & 80.18 & 82.10 \\
\hline Australia & 68.35 & 74.59 & 78.60 & 79.55 & 81.51 & 81.58 \\
\hline Japan & 57.51 & 60.05 & 68.68 & 71.73 & 74.51 & 78.37 \\
\hline New Zealand & 67.21 & 72.95 & 78.03 & 76.85 & 78.54 & 77.91 \\
\hline World & 43.94 & 48.40 & 52.86 & 56.78 & 60.11 & 61.69 \\
\hline
\end{tabular}

Source: [13].

The increase in the level of globalization took place in all the countries. In the period of 1990-2018, the index increased most in Portugal, Spain and Japan (by over 20 points), it means in less globalized countries. This increase was higher than in the world (17.75\%). The changes were much bigger in terms of percentage points, e.g. over $30 \%$ (the biggest in Japan $-36.6 \%$ ). They were similar to changes in the world (40\%). The lowest increase in the level of globalization (less than 10 points) was in Luxembourg, Belgium, Norway, Denmark and the United Kingdom. The changes were similar in terms of percentage points by about $11-12 \%$.

The largest increase was recorded by countries with low or average level of globalization in the base year. The smallest change was recorded by countries with rather high level of globalization in 1990. As a result, the differences between them decreased. If in 1990 the difference between the most and the least globalized was 23.6 points, it decreased to 13.3 points in 2018 . Hence the convergence in the level of globalization is apparent in highly developed countries.

The increase in the level of globalization was differentiated. The highest in the last decade of the $20^{\text {th }}$ century, rather low in the first decade of 21 st century (even decrease in New Zealand) and the lowest in the second decade of $21^{\text {st }}$ century (big decrease in Luxembourg and rather small in New Zealand, Italy, Sweden and the USA).

\section{The economic growth and socio-economic development}

The level of GDP per capita and its percentage change in the years 1990-2018 in highly developed countries are given in Table 3 .

Table 3. GDP per capita and percentage change.

\begin{tabular}{|c|c|c|c|c|c|c|}
\hline & \multicolumn{3}{|c|}{ GDP per capita, PPP (current int. US\$) } & \multicolumn{2}{c|}{ GDP per capita (constant 2010 US\$) } \\
\cline { 2 - 7 } & 1990 & 2018 & $1990=100$ & 1990 & 2018 & $1990=100$ \\
\hline Luxembourg & 29665 & 111908 & 377.2 & 65922 & 107243 & 162.7 \\
\hline Ireland & 13738 & 84069 & 611.9 & 24245 & 78765 & 324.9 \\
\hline Switzerland & 27595 & 68943 & 249.8 & 64344 & 78816 & 122,5 \\
\hline Norway & 18432 & 63756 & 345.9 & 60269 & 92121 & 152.8 \\
\hline USA & 23889 & 62641 & 262.2 & 36059 & 54542 & 151.3 \\
\hline Netherlands & 19145 & 56762 & 396.5 & 35703 & 55041 & 154.2 \\
\hline Austria & 19442 & 56253 & 289.3 & 33889 & 50250 & 148.3 \\
\hline Denmark & 18216 & 56120 & 308.1 & 44569 & 62889 & 141.1 \\
\hline Germany & 19423 & 54327 & 279.7 & 32337 & 47502 & 146.9 \\
\hline Sweden & 20121 & 53120 & 264.0 & 37565 & 57232 & 152.4 \\
\hline Australia & 17330 & 51545 & 297.4 & 35913 & 56919 & 158.5 \\
\hline Belgium & 18759 & 50775 & 270.7 & 33105 & 46683 & 148.0 \\
\hline Finland & 18149 & 48636 & 268.0 & 33515 & 48580 & 145.0 \\
\hline Canada & 20174 & 47870 & 237.1 & 36592 & 51358 & 140.4 \\
\hline
\end{tabular}




\begin{tabular}{|c|c|c|c|c|c|c|}
\hline UK & 16698 & 46240 & 276.9 & 28553 & 42986 & 150.5 \\
\hline France & 17624 & 45877 & 260.3 & 32524 & 43664 & 134.3 \\
\hline Japan & 19561 & 43349 & 221.6 & 38074 & 48920 & 128.5 \\
\hline Italy & 18547 & 42080 & 226.9 & n. a. & n. a. & n. a. \\
\hline New Zealand & 14864 & 41703 & 280.6 & 25126 & 38001 & 151.2 \\
\hline Spain & 13627 & 40845 & 299.7 & 22465 & 33146 & 147.5 \\
\hline Portugal & 11763 & 34065 & 289.6 & 16687 & 23738 & 142.3 \\
\hline World & 5494 & 17971 & 327.1 & 7186 & 10882 & 151.4 \\
\hline
\end{tabular}

Source: [12]

In 1990, the highest level of the GDP per capita (PPP, in international US\$) was reported in Luxembourg, next Switzerland, the USA, Canada and Sweden (above 20000). The lowest was recorded in Portugal, Spain and Ireland (less than 14000 US\$). In 2018, it was much higher in all countries, the highest was again in Luxembourg (almost 112000 US\$), next in Ireland, Switzerland, Norway and the USA (above 60000). 7 countries reached more than 50000 US $\$, 8$ countries more than 40000 US\$. Portugal, with GDP per capita at about 34000 US\$, is the poorest among the highly developed countries, though it is still almost twice as much as the world average. Ireland recorded the largest increase and moved from the $19^{\text {th }}$ to $2^{\text {nd }}$ position. The Netherlands, Luxembourg, Norway and Denmark also reached high increase (these countries tripled their GDP per capita). The lowest increase was reported in Japan. In 17 countries, the increase was smaller than the world average.

As far as GDP per capita (constant 2010 US\$) is concerned, the increase was much smaller. The highest was again recorded in Ireland. Other countries did not manage to double their GDP. The lowest increase was reported in Japan once more. Luxembourg recorded again the highest level of GDP per capita in 2018. The second place took Norway, next Switzerland, Ireland and Denmark. Portugal obtained the last place anew.

The changes have also taken place in socio-economic development. Human Development Index (HDI) and average annual HDI growth in highly developed countries are shown in Table 4.

Table 4. HDI Index and average annual growth.

\begin{tabular}{|c|c|c|c|c|c|}
\hline $\begin{array}{c}\text { Country } \\
\text { HDI rank }\end{array}$ & $\begin{array}{c}\text { HDI Index } \\
2017\end{array}$ & $1990-2000$ & $2000-2010$ & $2010-2017$ & $1990-2017$ \\
\hline Norway (1) & 0.953 & 0.76 & 0.27 & 0.17 & 0.42 \\
\hline Switzerland (2) & 0.944 & 0.67 & 0.47 & 0.18 & 0.47 \\
\hline Australia (3) & 0.939 & 0.36 & 0.27 & 0.24 & 0.30 \\
\hline Ireland (4) & 0.938 & 1.16 & 0.60 & 0.45 & 0.77 \\
\hline Germany (5) & 0.936 & 0.81 & 0.59 & 0.24 & 0.58 \\
\hline Sweden (7) & 0.933 & 0.96 & 0.09 & 0.43 & 0.50 \\
\hline Netherlands (10) & 0.931 & 0.55 & 0.39 & 0.32 & 0.43 \\
\hline Denmark (11) & 0.929 & 0.77 & 0.53 & 0.30 & 0.56 \\
\hline Canada (12) & 0.926 & 0.21 & 0.39 & 0.38 & 0.32 \\
\hline USA (13) & 0.924 & 0.28 & 0.32 & 0.16 & 0.27 \\
\hline UK (14) & 0.922 & 1.13 & 0.43 & 0.25 & 0.64 \\
\hline Finland (15) & 0.920 & 0.90 & 0.52 & 0.25 & 0.59 \\
\hline New Zealand (16) & 0.917 & 0.61 & 0.35 & 0.28 & 0.42 \\
\hline Belgium (17) & 0.916 & 0.80 & 0.33 & 0.21 & 0.47 \\
\hline Japan (19) & 0.909 & 0.48 & 0.34 & 0.32 & 0.40 \\
\hline Austria (20) & 0.908 & 0.53 & 0.66 & 0.20 & 0.49 \\
\hline Luxembourg (21) & 0.904 & 0.89 & 0.39 & 0.24 & 0.54 \\
\hline France (24) & 0.901 & 0.86 & 0.38 & 0.31 & 0.54 \\
\hline Spain (26) & 0.891 & 0.90 & 0.47 & 0.43 & 0.62 \\
\hline
\end{tabular}




\begin{tabular}{|c|c|c|c|c|c|}
\hline Italy (28) & 0.880 & 0.76 & 0.48 & 0.15 & 0.50 \\
\hline Portugal (41) & 0.847 & 0.98 & 0.46 & 0.44 & 0.65 \\
\hline
\end{tabular}

Source: [22]

Norway is the most developed country according to Human Development Report (2018), followed by Switzerland, Australia, Ireland and Germany. They took the first 5 places in the world ranking. 7 countries are at the top ten, $16-$ at the top twenty of the world HDI ranking. There are not big differences between them. The lowest position (less than 0.900 point) was taken by Spain, Italy and Portugal ( $41^{\text {st }}$ position). The other do not differ very much in GDP per capita ranking.

The average annual HDI growth differs from country to country, but the differences were not significant. The increase in the level of HDI index took place in all countries, the highest in Ireland $(0.77 \%)$, next in Portugal, Spain (less developed countries from this group), the United Kingdom and Germany (more developed countries). The lowest increase was in the USA, Australia and Canada (less than 0.4\%). The average annual HDI growth rate in individual decades differed significantly.

\section{Globalization vs. economic growth}

The influence of globalization (KOF Index of Globalization) on some indices of economic growth and socio-economic development in highly developed countries was examined in this paper. These are: GDP per capita (PPP, current international US\$), GDP per capita (constant 2010 US\$), HDI Index, percentage change in GDP per capita and average annual HDI growth rate. It was analysed by regressing KOF Index of Globalization (2018) as a dependent variable against the above mentioned factors as independent variables. Regression functions (y) and coefficient of determination $\left(\mathrm{R}^{2}\right)$ for these relationships, both for the general globalization index and the economic globalization index, are included in Table 5 .

Table 5. Regression function (y) and coefficient of determination $\mathrm{R}^{2}$.

\begin{tabular}{|c|c|c|}
\hline Correlation & Regression function & $\mathrm{R}^{2}$ \\
\hline $\begin{array}{c}\text { Index of globalization (2018) vs. GDP per capita, PPP, } \\
\text { current international US\$ (2018) }\end{array}$ & $y=3 E-0.5 x+84.437$ & $\mathrm{R}^{2}=0.0123$ \\
\hline $\begin{array}{l}\text { Index of economic globalization (2018) vs. GDP per } \\
\text { capita, PPP, current international US\$ (2018) }\end{array}$ & $y=0.0002 x+65.953$ & $\mathrm{R}^{2}=0.2469$ \\
\hline $\begin{array}{l}\text { Index of globalization (2018) vs. GDP per capita, } \\
\text { constant } 2010 \text { US\$ (2018) }\end{array}$ & $y=3 E-0.5 x+84.764$ & $\mathrm{R}^{2}=0.0126$ \\
\hline $\begin{array}{l}\text { Index of economic globalization (2018) vs. GDP per } \\
\text { capita, constant } 2010 \text { US\$ (2018) }\end{array}$ & $y=0.0001 x+71.041$ & $\mathrm{R}^{2}=0.1365$ \\
\hline Index of globalization (2018) vs. HDI Index (2017) & $y=50.518 x+39.508$ & $\mathrm{R}^{2}=0.095$ \\
\hline $\begin{array}{l}\text { Index of economic globalization (2018) vs. HDI Index } \\
(2017)\end{array}$ & $\mathrm{y}=58.28 \mathrm{x}+25.022$ & $\mathrm{R}^{2}=0.0323$ \\
\hline $\begin{array}{l}\text { Percentage change in level of globalization (1990-2018) } \\
\text { vs. Percentage change in GDP per capita, PPP, } \\
\text { current international US\$ (1990-2018) }\end{array}$ & $y=-0.0208 x+22.471$ & $\mathrm{R}^{2}=0.0503$ \\
\hline $\begin{array}{l}\text { Percentage change in level of economic globalization } \\
\text { (1990-2018) vs. Percentage change in GDP per capita, } \\
\text { PPP, current international US\$ (1990-2018) }\end{array}$ & $y=-0.0552 x+32.74$ & $\mathrm{R}^{2}=0.1377$ \\
\hline $\begin{array}{c}\text { Percentage change in level of globalization (1990-2018) } \\
\text { vs. Percentage change in GDP per capita, } \\
\text { constant } 2010 \text { US\$ (1990-2018) }\end{array}$ & $y=-0.0349 x+20.304$ & $\mathrm{R}^{2}=0.0348$ \\
\hline $\begin{array}{l}\text { Percentage change in level of economic globalization } \\
(1990-2018) \text { vs. Percentage change in GDP per capita, }\end{array}$ & $y=-0.0277 x+26.283$ & $\mathrm{R}^{2}=0.0761$ \\
\hline
\end{tabular}




\begin{tabular}{|c|c|c|}
\hline constant 2010 US\$ (1990-2018) & & \\
\hline $\begin{array}{c}\text { Percentage change in level of globalization (1990-2018) } \\
\text { vs. Average annual HDI growth rate (1990-2017) }\end{array}$ & $\mathrm{y}=6.7481 \mathrm{x}+15.031$ & $\mathrm{R}^{2}=0.0124$ \\
\hline $\begin{array}{c}\text { Percentage change in level of economic globalization } \\
\text { (1990-2018) vs. Average annual HDI growth rate } \\
(1990-2017)\end{array}$ & $\mathrm{y}=-4.3871 \mathrm{x}+24.108$ & $\mathrm{R}^{2}=0.0002$ \\
\hline
\end{tabular}

Source: Own calculation based on $[12,13,22]$

The above results show that there is a correlation between them, although it is really very small. In general, the relationship between them is greater in case of economic globalization index than the overall globalization index. As far as the percentage change of the Index of globalization (both overall and economic globalization index) vs. percentage change in GDP per capita are concerned, there is a negative correlation between them (very small). The greatest dependency exists between the level of economic globalization and GDP per capita.

It should also be mentioned that in all the cases the $\mathrm{R}^{2}$ is very low. It means that globalization (measured by KOF Index or percentage change in its level) should not be treated as a factor contributing to economic growth. Hence we cannot say that globalization has a positive effect on economic growth in case of highly developed countries.

\section{Conclusions}

Studies on the globalization and economic growth of highly developed countries allow us to draw the following conclusions:

Highly developed countries are the most globalized countries in the world. The level of globalization in individual countries varies but these differences are not large. The mediumsize European countries are the most globalized, while non-European countries are the least globalized. Their position is diverse as far as economic, social and political dimension of globalization are concerned. Their index of de jure globalization is much higher than their index of de facto globalization, especially in non-European countries.

Starting from the 1990s, the level of globalization of this group of countries has increased significantly, although it varied considerably. The highest increase was in the less globalized countries, the lowest in the most globalized. As a result, the differences between individual countries have significantly decreased. Thus we can see the convergence in the sphere of globalization in highly developed countries.

GDP per capita and its growth rate in this group of countries is diverse. However, the differences - with a few exceptions - are not very big. The positive impact of globalization on economic growth and socio-economic development was not observed in this group of countries. We cannot say that globalization promotes economic growth and socio-economic development in this group of countries.

\section{References}

1. G. Grossman, E. Helpman, Globalization and growth. American Economic Review 105, 100-104 (2015)

2. N. Crafts, Globalization and economic growth. A historical perspective. The World Economy 27, 45-58 (2004)

3. A. Dreher, Does globalization affect growth? Empirical evidence from a New Index of Globalization. Applied Economics 10, 1091-1110 (2006)

4. P. Martetens, A. Dreher, N. Gaston, Globalisation, the global village and the civil society. Futures 42, 574-582 (2010) 
5. A. Dreher, N. Gaston, Has globalization increased inequality? Review of International Economics 16, 516-536 (2008)

6. N. Potrafke, The evidence on globalisation. The World Economy 38, 509-522 (2015)

7. J. Villaverde, A. Maza, Globalization. Growth and convergence. The World Economy 34, 952-971 (2011)

8. S. Gygli, F. Haelg, N. Potrafke, J-E. Sturm, The KOF Globalization Index - revisited. The Review of International Organizations 14, 543-574 (2019)

9. A. Bergh, M. Karlsson, Government size and growth. Accounting for economic freedom and globalization. Public Choice 142, 195-213 (2010)

10. P. Samini, H.S. Jenatabadi, Globalization and economic growth: Empirical evidence on the role of complementarities. PLoS One 9, 1-7 (2014)

11. P. Hayaloglu, C. Kalayci, S. Artan, How does globalization affect economic growth across different income group countries? Osmangazi University Journal of Economics and Administrative Sciences 10, 119-151 (2015)

12. World Bank Database, https://data.worldbank.org

13. KOF Index of Globalization, http://www.globalization.kof.ethz.ch

14. A. Dreher, N. Gaston, P. Martens, Measuring globalization - gauging its consequences (New York, Springer, 2008)

15. Kearney/Foereign Policy, Measuring globalization. Foreign Policy 122, 56-65, (2001)

16. B. Lockwood, How robust is the Foreign Policy/Kearney Globalization Index? The World Economy 27, 507-523 (2004)

17. B. Lockwood, M. Redoano, The CSGR globalization index: An introductory guide. CSGR working paper. Technical report 155, (2005)

18. L. Figge, P. Martens, Globalisation continues: The Maastricht Globalisation Index revisited and updated. Globalizations 11, 875-893 (2014)

19. P. Vujakovic, How to measure globalisation? A New Globalisation Index (NGI). Atlantic Economic Journal 38, 237-237 (2010)

20. P. Martens, M. Castelli, P. De Lombaerde, L. Figge, J.A. Scholte, New directions in globalization indices. Globalizations 12, 217-228 (2014)

21. G. Gozgor, Robustness of the KOF index of economic globalization. The World Economy 41, 414-430 (2018)

22. Human Development Reports. United Nations Development Programme, http://hdr.undp.org 